\title{
Rewilding in practice: projects and policy
}

Meredith Root-Bernstein ${ }^{1,2}$, Jennifer Gooden $^{3}$, Alison Boyes $^{3}$

1) UMR SADAPT, INRA, AgroParisTech, Université Paris-Saclay, 78850, Thiverval Grignon, France

2) Instituto de Ecología y Biodiversidad, Santiago, Chile

3) School for Geography and the Environment, Oxford University, Oxford, UK

Highlights:

- At the project level, rewilding is interpreted and implemented in a variety of ways

- Rewilding projects are distinguished by place-based, adaptive, flexible approaches

- Projects focus on avoiding failure; policy focuses on producing evidence of success

- Transforming rewilding to best-practice policy risks loss of adaptive practices

\section{Abstract}

Rewilding is a conservation approach that is gaining increasing attention from academics, public opinion-makers, and policy makers. But what is rewilding? A large number of academic definitions coexist along with many different on-the-ground practices, and a lack of clarity at the policy level. Here, we trace the transformations of rewilding between practice and policy, following an anthropology of policy approach. We also enroll the "policy assemblage" concept to ask how rewilding is mobilized and how rewilding actors change their relations within assemblages across these practice-policy transformations. We look at rewilding is made into a reality at particular sites, as projects. We compare this to how rewilding is understood, positioned, used and produced at the policy level. We use a comparative approach, looking at projects in the UK, the Netherlands and Denmark, as well as policy frames and interactions in each of these countries and at the EU level. In order to 
secure future funding flows and institutional security, projects eventually (or immediately, in Denmark) present themselves as successful and normative within the existing regulations defining success or acceptability. At the same time, the practice of rewilding and the policy of rewilding define failure in different ways. At the project level, flexible long-term goals and adaptive learning allow failures to be avoided by definition. For policy makers, the fear of failure leads to avoidance of projects that cannot be defined as successful. We note that if high-level policy eventually defines normative success in rewilding it will probably do so in terms of its technical practices of reintroduction and passive management. It will be much more challenging to enshrine in policy the "meta-practices" of flexibility, long-term thinking and adaptive learning, which ensure rewilding success in practice. A broad acceptance of rewilding, as it is mobilized between projects and policies, may lead to radical changes in how rewilding is enacted.

Key words: Rewilding, policy, practice, adaptive learning, Oostvaardersplassen, Lille Vildemose, assemblage 
Introduction

Rewilding has emerged as an alternative approach to conservation. It puts emphasis on the reintroduction or introduction of megafauna, such as large grazers or large carnivores, with the goal of restoring ecosystem processes (Root-Bernstein et al. 2017). Existing rewilding projects are gaining increased visibility and legitimacy and new rewilding projects are being developed, in Europe, Siberia, and the Americas (Wilder et al. 2014; Lorimer et al. 2015; Kintisch 2015; Galetti et al. 2017). Early rewilding proposals clearly aimed to "do conservation differently," sometimes provocatively so (Rubenstein et al. 2006; NoguesBravo et al. 2016). European varieties of rewilding, emphasizing open-ended passive management, contrasted with European Union (EU) conservation policy prescriptions focusing on highly-managed compositionalist goals (Callicott et al. 1999; Jepson 2016; Robert et al. 2017). However, as rewilding projects develop new variations, and move into new policy realms, it has become less clear what rewilding is (Jørgensen 2015).

We trace the transformations of rewilding practice between projects and policy. In practice, rewilding projects are a multiplicity of things, responding to site history, social context, geography, ecological condition, and feasibility in both physical (how do we move that animal?) and legal senses (are we permitted to move that animal?). Here, we are interested in the forms of production employed by project managers, scientists, and policy makers, to realize rewilding. We are also interested in how the products of these different enactments of rewilding are translated, interchanged, and transmuted into each other. We trace some of the zigzags between sites and across policy levels, and the tensions between the unifying concept of rewilding and its place-based instantiations. Finally, we look at how failure is avoided in different ways by rewilding projects and by policies, and whether these can be compatible or are bound to be mutually unintelligible. 
European policy makers are cautiously moving to embrace rewilding. A policy brief aimed at the European Commission, subtitled "Creating an enabling policy environment" (Jepson \& Schepers 2016), presents rewilding as the "next logical step in an on-going process of EU nature policy development." In 2017, a financial instrument of the European Commission and the European Investment Bank, the Natural Capital Financing Facility (NCFF), gave its first multi-million euro loan to Rewilding Europe's entrepreneurial branch, Rewilding Europe Capital. How did rewilding evolve from the situated and unruly tinkering practices of unrelated projects, to being trumpeted as an emerging normative concept, heir apparent to European policy?

We respond to this question by drawing on material from the authors' research in the UK, the Netherlands and Denmark. We first consider the European policy and academic context in which rewilding projects and definitions emerged. We then trace the development of rewilding practices in the UK and the Netherlands, which we identify as "first wave" rewilding, and Denmark, which we identify as "second wave" rewilding. To address what kinds of relations site-based rewilding projects set up, and how they function successfully or avoid failure as projects, we consider the range of visions that projects had for rewilding their sites, the strategies they used to achieve these visions, and the means of validation they appealed to. Finally, we ask how European policy has responded to the increasing numbers of rewilding projects and their attempts to secure their long-term existence. Our focus is not on the flow or dissemination of ideas about rewilding, but on the acts that create translations or modified relations between practices - practices of site-based rewilding projects, and practices of policy making. We engage with different theoretical positions about what policy is and how it relates to projects, in order to ask how we might expect rewilding to change if it succeeds in becoming best-practice conservation policy, as many of its advocates promote (e.g. Pettorelli 2018; Jepson 2018). We start by asking what policy does, and what it has to 
do with site-based projects.

Theoretical Background: What policy does

The anthropology of bureaucracy and the anthropology of policy typically focus on programmes affecting marginalized people, such as immigration procedures and development aid projects. Less research has focused on conservation policies (see Telesca 2015). In this literature, anthropologists observe a "policy-practice problematic" (PPP), that is, a gap between policy and its implementation, including its discretionary components and ad hoc tinkering at "street level” (Hoag 2011; 2014). The PPP develops out of interactions between multiple stakeholders and material conditions, learning processes, power relations, chance events and unintended outcomes (Fergusen 1994; Heyman 1995; Mosse 2004; Rocheleau 2008).

Mosse (2004) argues that policy merely legitimates practice, with the legitimization of practice driven by personal relationships, organizational capacities, and the desire of institutions to maintain internal coherency. In a development setting, Fergusen (1994) claims that projects do not solve problems, but rather create and institutionalize new classes of problems that have better "political intelligibility" (p. 20). Anthropologists thus ask whether practice should best be described as "failed policy" (Hoag 2014) or "de facto policy" (Mosse 2004) or whether policy represents "potential practice", generating hope as much as frustration and disappointment (Hoag 2014).

The anthropological perspective on the policy-practice relationship contrasts with the perspective of conservationists. Reflecting their own positionality, conservationists tend to see policy as something they need to influence and capture (Watson et al. 2005; Pettorelli et al. 2018). From an academic research perspective a distinction is often made between being policy-relevant, which is considered good, and policy-prescriptive, which may be 
inappropriate since it bypasses non-scientific considerations for decision-making (Alpert \& Keller 2003). Literature in this area considers the relative influences of social values and scientific data in shaping policy, with the assumption that policy directs and facilitates conservation on the ground (Jepson \& Canney 2003; Mace 2014; Tallis et al. 2014).

More familiar to human geographers is a governmentality and assemblages approach to policy. In this view, governmentality renders ecology as an object of governance; this can be thought of as an assemblage of species, places, processes, people, and regulations (Gorur 2011; Öjehag-Pettersson 2015). Any given assemblage, if it avoids enacting various interpretations of failure (Howlett 2013), can be promoted as successful and as representing the ideal of best practice (Webber 2015). Mobile policy assemblages - that is, policy assemblages that move, are transferred, or adopted from one project locality to new onesare not inherently mobile (they are not inherently easy to adopt or applicable to many places) or even inherently best. Simply, and tautologically, they are those that are mobilized to perform best practice (Temenos \& McCann 2013). One way this happens is that their particular configuration becomes a conceptual "black box" (Goulden et al. 2015) - an assemblage in which the specificity of the relational inner workings has been lost. It is the observable features of the mobile black box assemblage that are reproduced in other contexts. Through a process of local "bricolage" or tinkering (Stone 2017; Öjehag-Pettersson 2015), these mobilized assemblages come to seem "strangely familiar," both local and acontextual (Temenos \& McCann 2013). In some cases, the tinkering itself creates a failure (e.g. “inappropriate or uninformed transfer”, Stone 2017).

A key difference between this approach and the anthropological approaches cited above is that the anthropologists see a disconnect between a policy sphere, which has its own practices and products, and a project sphere responding to other concerns, while the assemblage concept emphasizes the relational integration between these spheres of practice, 
implying that they jointly travel, morph and are adapted to varying contexts. The assemblage concept thus emphasizes the relations among the actors, even though those relations may be hidden or lost during policy mobility. Our interest here is, first, to trace the coming together of rewilding assemblages, and then to understand the elasticity of the relations between practice and policy as each experiences different mobilities pulling them in different kinds of transformational and spatial directions. In other words, we use the anthropology of policy approach to ask how, specifically, the internal relations of rewilding assemblages are reformulated during transitions from local projects to supra-national policies.

\section{European Conservation Policy and Academic Context}

The Birds Directive (EC/1979) and the Habitats Directive (EC/1992) are the cornerstones of the EU biodiversity regulatory framework. The directives establish favourable conservation statuses for habitat types (site-level measures) and wild fauna and flora (species-level measures) that have been designated as being of "Community interest" (Scheuer, 2005). The Directives require each Member State to designate sites of community importance (SCIs) and special areas of conservation (SACs) representing these species and habitats, constituting the Natura 2000 network. Natura 2000 sites now cover about $18 \%$ of EU territory plus marine areas (Donald et al. 2007).

The status and change of habitats is a key indicator for biodiversity conservation success in Europe (Bunce et al. 2013). Conservation targets are based on maintenance of specific site attributes chosen to signify the site's condition (Haslett et al. 2010). Species and habitats categorized as rare or threatened are identified, listed, monitored, modelled and managed, with population dynamics the main accounting tool to measure the success of landscape management (Lorimer and Driessen 2014).

EU policy is translated into member states' national policies, with roughly $80 \%$ of 
what becomes national environmental legislation in EU Member States originating at the EU level (Scheuer, 2005; Haigh 1992). Environmental interest groups who mobilise at the EU level are thus influential in shaping outcomes of environmental policy throughout Europe (Greenwood, 2011). The Commission also looks to environmental NGOs for scientific data (Mertens, 2013; Armstrong et al., 2010). This reflects the open door nature of EU decision making, whereby the Commission pushes for the inclusion of numerous civil society groups in decision-making processes at all stages of the policy cycle (Lenschow, 2013).

Conceptually, there are at least three major policy frames now influencing environmental and conservation policy instruments (see Figure 1). In light of these evolving conceptualizations, each of which draws different players and power dynamics into the realm of environmental policy, the EU has been under pressure from some member states to review its “aging” conservation policies (Jackson, 2013). The European Commission conducted an “evidence-based critical analysis" or "fitness check" of its nature policy in 2015-2016 (European Commission 2016). While rewilding advocates speculated that this exercise might highlight shortcomings that they could capitalize on, the European Commission concluded that their current policy is "fit for purpose." A more flexible target seems to be the EU Biodiversity Strategy. In 2011 the EU formalized a Biodiversity Strategy for 2010-2020 with goals for halting the loss of biodiversity and degradation of ecosystems and restoring $15 \%$ of degraded habitats, in line with the Aichi targets (2010) of the Convention on Biological Diversity (http://ec.europa.eu/environment/nature/biodiversity/strategy). The next iteration of the European Biodiversity Strategy, in 2020, is the lobbying target of group of major European NGOs and research units that have signed a memorandum of understanding to promote rewilding (https://www.rewildingeurope.com/news/green-shoots-for-rewilding/).

Alongside developments in policy such as the EU biodiversity strategy, academics have taken an increased interest in rewilding. In recent years, various academic reviews and 
thought pieces have declared what rewilding is, positioning it according to the authors' favoured concepts (e.g. Sandom et al. 2012; Seddon et al. 2014; Lorimer et al. 2015; Pereira \& Navarro 2015; Jepson 2016; Svenning et al. 2016; Corlett 2016a, 2016b; Galetti et al. 2017). For example, while Jepson (2016) tries to capture the interacting currents of a diverse set of ideas about restoration, transnational conservation, critiques of "nature," coexistence with carnivores, and urbanization of the populace, Sandom et al. (2012) focus on conservation design issues (size, connectivity, keystone species) and Corlett (2016b) divides rewilding into four distinct approaches: Pleistocene, Trophic, Ecological and Passive. Numerous papers have also made policy recommendations primarily focused on the removal of bureaucratic barriers so that rewilding projects can access conservation funds and programmes (e.g. Pettorelli et al. 2018). The discourse on a definitive declaration of a normative consensus around rewilding has produced a large literature that, however, rarely draws on original data. We propose than an empirical analysis of what rewilding is and how policy engages with it will both provide pragmatic insights to practitioners, and theoretical insights relating to how people act to create and institutionalize new relations with the environment.

Rewilding's Emergence in the Netherlands and the UK: Tinkering with the Possible The "first wave" of rewilding in Europe emerged as a novel approach to nature conservation in the 1990s. Its current high profile as a conservation "movement" is represented by flagship sites such as the Oostvaardersplassen in the Netherlands and Wild Ennerdale and Alladale Wilderness Reserve in the UK. One of us (JG) visited six study sites in the UK and two in the Netherlands (Table 1), interviewing leadership or key staff at each. In addition, she received 11 responses to a follow-up survey sent to representatives of the sites. All interviews and surveys were conducted during the summer of 2014. Interviews were 
recorded and transcribed. In the following text, quotes are attributed by last name of the interviewee.

Several of the projects included in this study were pioneers in the rewilding domain, and most had begun to depart from more conventional conservation strategies prior to the widespread recognition of the rewilding label. As a result, despite their current recognition as rewilding projects, they came into being on parallel but independent pathways. Here we draw on observation and interviews at the eight study sites to better understand rewilding's emergence in Europe. We first discuss the projects' visions, followed by a discussion of strategy, and, ultimately, validation.

Vision

Each rewilding project originated with an impulse to let natural processes occur more freely on the land. The oldest projects currently characterized as rewilding were planned interventions in the Netherlands, where they were recognized as "nature development" or "new nature" projects. The Oostvaardersplassen came about when large numbers of geese, spoonbills, and cormorants colonized an undeveloped, marshy polder in the 1970s. The National Agency for IJsselmeer Polders introduced backbred Heck cattle to maintain open wetland habitat for birds through grazing, followed by Konik horses and red deer. The Oostvaardersplassen remains perhaps the most ambitious and radical of rewilding sites, with a continued emphasis on resource-constrained herbivore populations.

Millingerwaard arose from a more human-focused approach. The project came about in the early 1990s as a strategic land use plan to simultaneously create nature reserves and provide farmers with more suitable land along the Waal river. With a vision informed by demographic projections and an understanding of the needs of diverse landowners, project leaders were prepared when significant floods created a public emergency and a subsequent opportunity to introduce new approaches to water and land management. 
Whereas Oostvaardersplassen and Millingerwaard were planned interventions, other sites, like Wild Ennerdale, sought to relinquish control. Curious about the lack of communication amongst the three major landowners in the valley, Ennerdale's pivot to rewilding began in conversation between two employees, one from the Forestry Commission and one from the National Trust, taking long walks through the valley to discuss what it would be like to let nature determine how the valley changed over time. Their vision was about process, rather than endpoint. As the plan rolled out, people asked what it would look like in ten years' time, to which we would reply, "We don't know. It's going to look like whatever it looks like" (Holt). There was no prescribed outcome; the whole ethos was that natural processes would decide. The lack of a constraining plan was described as refreshing and freeing, yet difficult because people assumed the core team was hiding information: the idea of letting go was too foreign to accept at face value.

Several sites contrasted themselves with mainstream conservation organizations in their planning horizons, where they reported that 5- to 10-year management plans are the norm. Millingerwaard set out with a 20-year plan - not for the ecosystem restoration, but for the land allocation plan that would allow the team to begin long-term restoration. Trees for Life, in the Scottish Highlands, described their programme as a 250-year vision to restore Caledonian forest. They have even proposed a target date for wolf reintroduction: 2043, exactly 300 years after the last wolf was reputedly eradicated from Scotland. And Wild Ennerdale reported that their processes had only just begun. "Really, you need to come back in 500 years" (Holt).

Within the broad framework of letting natural processes unfold over long time horizons, rewilding projects' visions were highly contextualized. Wild Ennerdale began with and maintains a slowly unfolding vision of what the valley could become. It is "not a project; it's a partnership, a relationship between a set of organizations, the people who work in them, 
the people who live and work in this valley, and this landscape" (Browning). Representatives used the metaphor of concentric rings. "There's an inner circle, which is the landowning group plus Natural England. Then a slightly wider group we have liaised with, our advisory group, the national park, and local bodies. And a much larger and more loosely constructed group of people who are interested in what we are doing or whose views we want to hear" (Holt). This high level of engagement means that local perspectives were deeply embedded in the project's vision for the future.

At rewilding projects owned by private individuals, such as Alladale Wilderness Reserve and Knepp Castle Estate, there are fewer decision makers, and control is more concentrated, so the visions and personalities of landowners inevitably shape the landscape. Yet this is also true of some projects operated by organizations. Rewilders like Frans Vera and Alan Watson Featherstone have become legendary, and perhaps inseparable from the organizations' rewilding visions themselves.

Place, too, shapes rewilding. As a polder reclaimed from the sea less than 50 years ago, surrounded by southern Flevoland cities of the same era, practitioners at the Oostvaardersplassen note that its very newness has fostered an openness and willingness to experiment that would be difficult to replicate elsewhere in tradition-steeped Europe. The Knepp Castle Estate, by contrast, has been in the Burrell family for 220 years, yet while embeddedness in history and requirements of funding necessitate that some elements of the cultural landscape be restored and preserved, place has also created opportunities for Knepp. A location in the affluent and populated southeast of England, with proximity to developed areas, means that post-agricultural buildings can be converted and leased to small enterprises to generate revenue, and its agricultural history positioned it for a mode of rewilding that brings alternative value to marginal agricultural land. "Place and landform and land mass, they make a huge difference. It matters where your land is. What is happening here just 
wouldn't be feasible in the Midlands" (Burrell).

The visions of rewilding projects included not only their goals and objectives, but also, implicitly, their organizational self-concept. A recurring theme was innovation. Faced with restrictive rules for forest development in the floodplain at Millingerwaard, the ARK Foundation developed the concept of "cyclical rejuvenation," which involves using heavy machinery to mimic the effect of natural processes such as erosion of alluvial forest, clearing of the river's side channels, and inundation of riverbanks. Restricted to rigid tree planting densities by the Forestry Commission, Blaeneinion developed a technique of mixing canopy and understory species to increase biodiversity. At Wild Ennerdale the landowners are "pushing back the boundaries of traditional policy and finding out where the edges are. You know, some of those edges are only edges because we have not stepped over them in the past" (Browning). Innovation was not only absolute, but relative, and a source of pride:

"When we started ten years ago, it was miles out in front of anything anyone had ever dreamt about. We have asked ourselves a question more recently: are we still leading the way, or have other people caught up?... I suppose one of the things we'll have to look at going forward is what's next. It is probably slightly at odds with the idea of just leaving things to do what they want to do, with the idea of natural processes, but this has always been a leading edge project, and I think we quite pride ourselves on that." (Holt)

The sites in this study were selected because they were sites that were commonly identified with the rewilding movement in scoping interviews. Yet, in 2014, when site visits were conducted, most of the sites did not publicly use the term rewilding to describe their activities. In interviews and the survey, interviewees from six sites confirmed that they preferred other terminology, such as "natural processes," "habitat restoration and education," "large ecological entities," "ecological restoration," and "bringing the land back to life." At that time, an examination of the projects' websites and a selection of promotional material confirmed this finding, with only two websites using the word rewilding. Some interviewees described the word rewilding as provocative, though others said they might use the word 
more in the future as it was gaining profile. A 2017 review of those same sites found that three were using the term rewilding on their own websites, and five were listed as projects by either Rewilding Britain or Rewilding Europe. Thus, although each project responded to unique site-specific and contingent problematics and possibilities, a recognition was emerging among the practitioners themselves that what they were doing was coalescing into a recognized and shared approach.

Strategy

The rewilding projects in this study began with visions to restore natural processes over long timelines. Projects employed a range of strategies for achieving these visions. As they began to shift from the status quo, they inevitably encountered regulations that created barriers to change. These regulations governed dangerous and wild animals, animal byproducts, agricultural policy, conservation land designations, and more. The friction between regulations and rewilding practice was rooted in the regulations' more static and controlled notion of nature, which was inconsistent with the goals of rewilding projects (Gooden 2016).

Projects found a variety of creative ways to comply with regulatory requirements, with mixed success. For example, at Blaeneinion, the project wanted to reintroduce beavers due to their significant impacts as keystone species of riparian ecosystems. However, beaver reintroduction was not authorized in the UK, so the project managers built a large enclosure around a pond to create, in effect, a "private beaver collection." While not the ideal situation, it provided space for a beaver dam and associated ecological impacts, and the mechanism allowed them to achieve their goals within existing regulations.

At Glenfeshie, a rewilding project in Cairngorms National Park, practitioners responded to inflexible regulations by tinkering with the problem definition. When Forestry Commission guidelines prescribed a planting density of 1600 trees per hectare, the managers of Glenfeshie responded, “That's too dense; it will look like an industrial forest." Glenfeshie 
managers proposed accepting only 400 trees and one-quarter of the funding, but for the Forestry Commission, that "does not compute; it's not in the book" (Hetherington).

At other times groups employed a loose interpretation of the rules or engaged in active noncompliance, particularly if the risk was low. While not a site in this study, a wild beaver population was established in Tayside, Scotland, as a result of either escape or illegal release. Similarly, feral pigs were released in the Highlands and have since become established. "It illegal and not to be condoned, but it is borne out of frustration with regulatory process" (Gilbert).

Funding bodies, such as governments or NGOs, were another source of regulatory hurdle, though rewilding projects generally were cautious and strategic about their use of external funding. Government funding proved difficult due to the fact that time frames for government grants and political cycles were shorter than the time needed to allow ecological processes to operate. At Wild Ennerdale, it was observed that "funding is generally for a short period of time, five or ten years, and you need to measure results. You need to say exactly how you are going to go about getting to those results and what it is going to look like” (Holt). Moreover, "Typically it takes 10-15 years for a change in the landscape to demonstrate results. When you think about it, that could be two to three parliaments and four to five environment ministers" (Browning).

Rewilding projects contrasted themselves with other conservation organizations that designed projects around funding opportunities, leading others to "mission creep" and a focus on the short term. Wild Ennerdale, for example, reported using policies and subsidies as tools to deliver on the vision, with the caveat that "If they don't help our vision, we won't work with them" (Browning). Similarly, as a rewilding project on private land, Glenfeshie was deliberate about including government financing of restoration activities. This served two purposes: one, it locked in commitments to ensure rewilding activities were continued into 
the future, and, two, it improved replicability: "If it is $100 \%$ funded by a billionaire, how replicable is that?" (Hetherington).

Perhaps the most central strategy used by rewilding projects was development of strong, trust-based relationships. Wild Ennerdale placed the relationship amongst partners at the centre of their rewilding strategy. The result of their partnership, based on years of collaboration, led to more flexibility than is usually possible within the structures of large organizations like the Forestry Commission or the National Trust. "We are very fortunate that our organizations have stayed with us. They've had some concerns, but said, 'We trust you, experiment away"” (Browning). It was suggested that organizations need to give people the flexibility and responsibility to do things that are outside the organization's experience and which don't fit well with the policy, as this facilitates innovation.

When dealing with government funding and oversight, the relationship between a project and the associated government civil servant was also important. At Knepp, it was noted that the attitude of one's case officer must be in support of the project and understand what the project is trying to achieve. The case officer can then set goals that are achievable, allowing for the unpredictability of nature rather than being "fixated on targets and numbers like conventional conservation" (Burrell). The support of higher-level decision makers is also indispensable. When a project is really pushing the boundaries, "In these situations you need a civil servant who is high enough to be a decision maker. If you try to run these projects lower down the pecking order, you then end up with a system that doesn't work at all because they haven't got the power to think outside the box" (Burrell). To make this happen, projects rely on networking and strategic relationship building. This may come in the form of an advisory board, a group of experts who understand the vision. Beyond support, advisory boards challenge projects to push the boundaries. At Wild Ennerdale, the view is that "we need people to challenge us to think beyond the boundary of WE at times, and say, 'Right, 
this is going on at Knepp or Oostvaardersplassen. What about doing something like that here?"' (Oakley). Yet ultimately, these relationships are means to an end, a way to fulfil the mission. "Sometimes we might alienate people, but I think there will be reasons why. Whatever we do has to fit and complement our vision" (Oakley).

Wild Ennerdale echoed the need for decision-maker support with a coordinated and intentional advocacy programme. "[We have] a very definite and non-apologetic advocacy policy amongst our own organizations.... Whoever the new person [at our company] is, we get them out to Ennerdale and show them around and explain what's going on. And the same goes for the Commission, and the National Trust, and Natural England, so there's a constant stream of senior people from those organizations who we attempt to get to buy into Ennerdale."

As the audience broadens, moving away from the core project leaders to the public, projects deliberately framed their messages to highlight non-ecological benefits and motives. For example, at Millingerwaard, an important component of the rewilding plan was "making room for the river," allowing it to wander naturally and flood seasonally, in a way that reduced flood risk in inhabited areas. "This is nature that is good for all of us, for everybody, because it is making our environment safer" (Bijl). Explaining benefits in terms of water management made the conservation action more universally acceptable.

At Knepp Castle Estate, the communication process involved thinking about how the regulatory requirements could be satisfied through alternative framing. "You have to say you are a farmer running an extensive farming system on a bit of land. And it just so happens that you're so extensive that you are allowing some natural processes to happen, and at the same time you're producing organic, free-roaming, pasture-fed meat" (Burrell). "That's what you have to stress instead of saying, 'We've given up farming.,"

Validation 
Early rewilding projects may have begun in isolated ways, but, once developed, they began to seek validation, through policy and with one another. Despite concerns that Natura 2000 necessitates halting ecological succession with active conservation management, the Oostvaardersplassen reported benefitting from a Natura 2000 designation because it prevented land use developments that would affect the project negatively (de Snoo). Similarly, Wild Ennerdale found benefit in having a variety of designations on the site. Just under half of the Ennerdale Valley was designated as SSSI or SAC (Site of Special Scientific Interest, a UK designation, and Special Area of Conservation, a designation within the Habitats Directive), and the project also had archaeological and cultural designations protecting over 500 scheduled ancient monuments and archaeological features. Sometimes these created the very regulatory barriers that had to be addressed creatively, but they also lent legitimacy to the project.

Over time projects began to seek changes in policy to make rewilding easier. The most sought-after policy change was legitimizing wild land as a worthwhile land use, particularly in agricultural policy. As it stands, farmers can be compensated for many conservation actions, but not for simply leaving the land alone to let nature act on its own. Another policy that rewilders sought to change was making Natura 2000 legislation better fit with the ecological thinking that has influenced rewilding. "Back in the 1990s, when the European legislation was written, we were trying to maintain things. Now there is a growing sense of needing to push things forward" (Hetherington).

Advocacy organizations such as Rewilding Europe and Rewilding Britain have formed to fill this space: to bring rewilding forward as a legitimate means of conducting conservation in the $21^{\text {st }}$ century and to create policy change to facilitate rewilding. Yet collaboration with a broader group of stakeholders has come with its own set of challenges, as enthusiasts, policymakers, and academics get involved. "[The partnership] has sometimes 
been challenged by wildland enthusiasts, and particularly academics, who would like to see our partnership take a much more radical approach to wilding in Ennerdale...But those of us who are doing the job on the ground go back to our core vision: we're about natural processes and we're about people. It's a living and working landscape, and our starting point needs to be considered" (Oakley).

Rewilding by the book: Detaming Denmark

Denmark has a profoundly agricultural landscape, history, and self-concept. The government strongly supports and protects farmers' interests and shows little interest in 'nature', as opposed to 'environment' or 'climate'. However, a generational and cultural shift appears to be taking place, which has resulted in social and political support for forms of nature management that restore less agricultural-looking landscapes. This has led to "second wave" adoption of rewilding practices.

One of us (MR-B) visited four rewilding sites in Denmark (Lille Vildemose, Gedding Kasted Mose, St. Raabjerg, and Mols National Park), interviewed people associated with three more by phone (the national beaver reintroduction site at Klosterheden, Kleland Deer Park, and a project of the Danish Armed Forces), and received 11 responses to brief surveys sent to 38 land managers of public lands with grazing management or rewilding projects (for an overview of included projects, see Table 2). Interviews were in English and surveys were in Danish. In this section, people who gave permission are identified by name where cited, while those representing public projects are identified by the initials of the site name, as interviewees indicated that as civil servants they spoke for the site. The Kleland Deer Park is the only private rewilding project in Denmark; all other rewilding projects in Denmark are managed by public entities, often in areas that are privately owned but within protected area designations (Natura 2000 areas or "Section 3" areas under an older Danish conservation 
law). Here we follow the same format as in the previous section, first considering the projects' visions, then their strategies and finally their means of validation.

Vision

A succession of waves of interest in naturalistic grazing and rewilding in Denmark points to a rapid evolution in both nature management and agriculture, and ideas about their relationship. The European bison reintroduction project on Bornholm island cited a political context of "increased interest in biodiversity conservation" (notes Bornholm). One project manager stated about a year-round naturalistic grazing demonstration project started in 2013, "I didn't think of 'rewilding,' but of 'year-round-grazing' since I had at that time some information about how it is good for many groups of organisms, e.g., dung beetles. But today I would think of rewilding, if I were in the same position."

Rewilding projects in Denmark could be described as "second wave" rewilding. Several managers reported becoming aware of rewilding through pamphlets, public lectures and research activities by researchers at Aarhus University. Municipal land managers further learned from each others' experiences and were inspired by conferences and trips to protected areas in Germany, the Netherlands and the UK. Lessons learned abroad were filtered through the requirements for conservation and/or grazing in Denmark. As a consultant on the Wild Horses of Langeland project on the island of Fyn wrote,

"There are things that we saw abroad that for several reasons we wanted to implement, on the grounds of economics, ethics, rules for livestock and efficacy of grazing. We are used to complying with the rules and restrictions when implementing changes in nature, and so we had no major problems in our project, any more than in the other projects we have been responsible for. We decided after careful evaluation to use horses because we estimated they would be a main attraction and the least bureaucratic to work with...We got inspiration from the foundation Stiftung Naturschutz in northern Germany, especially in relation to capture and physical handling of horses." (translation MR-B)

Steffen Bengtsson, an environmental consultant involved in several Danish rewilding projects, first got into rewilding when working for the Kleland Deer Park, where the owner 
wanted to focus on red deer management, but not for hunting as is usually the case in Denmark. The Nature Agency, in exchange for allowing the deer to be fenced in, insisted that the area be managed for biodiversity. As Bengtsson recalled, "The more we worked on that part [managing for biodiversity], the more interesting it got." This led to the development of an ecosystem-focused rewilding approach, inspired in part by visits to projects in the Netherlands and Germany, which already had substantial experience with rewilding-style project implementation.

Rewilding projects were tailored to the sites and social situations in which they were embedded. On the whole, the rewilding contexts in Denmark are relatively uniform due to the homogenization of the landscape by modern farming. Each site, however, had differing sitespecific restoration goals, such as aquifer protection at Gedding Kasted Mose, deadwood protection and heath regeneration at St. Raabjerg or high bog restoration at Lille Vildemose. Strategy

The main Danish strategy for implementing rewilding was to "comply with the rules and restrictions when implementing changes in nature" as the interviewee cited above put it. Thus, the ultimate goals and the proximate mechanisms to achieve them were subsidiary to the need to make things work successfully within the logic of existing policies. Nevertheless, the projects differed in their approaches.

The Mols National Park project was an explicitly academic rewilding project. The public event to release Exmoor ponies at Mols was opened with a talk by the Natural History Museum director about the use of beetle fossils to reconstruct dung densities in paleoecological studies. The Mols project, as part of its demonstration element, also sought to create a "data infrastructure" for the sharing of rewilding monitoring data with researchers and planned to base the population control of their reintroduced grazers on a population simulation model. 
Other projects relied on the "inflexible bureaucracy" of farming and conservation regulations to guide implementation. Several projects, such as the St. Raabjerg site and the Geding Kasted Mose site, used the EU's High Nature Value agricultural programme, part of the CAP, to pay for rewilding. In this programme, sites that meet certain criteria for high nature value pastureland receive subsidies to support naturalistic grazing management meeting specific criteria. Land managers tried to be creative in adapting an agricultural subsidy programme for rewilding. At Geding Kasted Mose, for example, they had constructed their mandatory livestock shelter with a green (vegetated) roof and in a position where it was masked by a slope, so that it was almost invisible from a distance. St. Raabjerg used subsidized cattle grazing and mowing to convert improved grassland back to heath $-\mathrm{a}$ protected Natura 2000 habitat - while maintaining intact a rare stand of dead wood and its associated species and simultaneously preventing forest regeneration. These projects also sought appropriate domestic species beyond cattle and horses-Geding Kasted Mose planned to use water buffalo, and at St. Raabjerg the manager was hoping to find a goat producer to work with.

Water buffalo were an attractive animal for reintroduction in Denmark because they were technically domestic. However, a water buffalo introduction project that hoped to establish grazing in wet areas in Egedal Municipality ended with the bulls being shot, since they were too aggressive towards visitors. Although it "was fantastic for nature conservation in a wet place" (notes Edegal), they had no future plans to introduce castrated water buffalo or any other species. Failure, it seemed, was often accepted rather than seen as part of a process of adaptive management.

In contrast to the UK and the Netherlands, Danish rewilding is almost entirely conceived and carried out by civil servants. Most project managers were both excited by the new opportunities for nature and agricultural management and largely resigned to working 
within the limits of the path of least resistance. As one civil servant said, "I told my colleagues, 'one week before I retire, I will find some beavers in Germany or Poland and let them out [in the reserve], and then you can fire me."”

Validation

Despite an increasing interest in rewilding across Danish municipalities, the perceived legitimacy and feasibility of rewilding varied between municipalities and projects. One municipal land manager replied to the survey, "The municipality carries out as a starting point only 'within the regulations' projects... which can be put into place through voluntary agreements with landowners... 'rewilding' projects will probably be challenged" (notes Fredrikshavn). In this sense, rewilding was perceived as non-legitimate because it was expected to create social conflicts.

What rewilding meant varied between projects. The consultant Bengtsson felt that many projects in Denmark were not really rewilding. Both the Mols project and the Lille Vildemose project were convinced that they were doing "real" rewilding, although they were doing very different things. Lille Vildemose, the site of a former high bog and industrial peat extraction site, reintroduced five juvenile moose from Sweden and 22 red deer in 2016, into a marsh that they intend to reconvert over several hundred years to the rare high bog habitat. They also plan to reintroduce European bison and horses and hope that beavers and wolves will naturally spread into the area, in order to "bring back dynamic processes" (notes LV). Lille Vildemose also benefited from the support of the private O.V. Jensens Fund, making possible expensive engineering interventions designed to safeguard the high bog and its continued formation, including the delivery by helicopter and manual installation of impermeable membranes to raise the water level without damaging the sphagnum moss surface. The Mols project, by contrast, released 12 Exmoor ponies and 13 Galloway cattle in 2016 into a 130 ha fenced area and had no plans to release other species or perform any other 
kinds of land management. The rewilded area was already classified as farmland and had a shelter for the animals. They plan to monitor the population of ponies and cattle, culling or selling them to maintain a stable population, creating a "realistic grazing pressure" similar to what you would have "if you had wild animals" with predators (notes Mols). Lille Vildemose is the largest protected area in Denmark, at 7500 ha, and sees itself as consequently different from other Danish rewilding projects. The Mols project, by contrast, was specifically set up to promote and legitimize rewilding adoption by farmers. It claimed its own legitimacy not by showing how to implement grand visions despite agricultural regulations, but by setting up the most feasible situation possible and producing scientific data on it.

Funding made projects possible and also conferred legitimacy on them. The Mols rewilding project was the first project funded by a new consortium called Dansk Naturfond, comprised of the Nature Agency, the private O.V. Jensen's Fund, and the private Villum Foundation, a fact that was highlighted at the horse release, where a representative of the fund gave a speech. The LIFE project in Lille Vildemose refused to pay for the moose reintroduction, arguing that it was too controversial, and this was instead paid for by the O.V. Jensen's Fund. The sponsorship of private Danish funders was clearly a key factor in making rewilding projects possible and respectable in Denmark.

The issue of leaving large animal carcasses on site illustrates how particular people had specific agencies that might help to bend certain regulations. Lille Vildemose had been working with Bengtsson and felt he would be key to being able to negotiate leaving out moose carcasses at the site (notes LV). Bengtsson pointed to a "growing understanding that we can experiment with how we see animals - horses can be both for riding and for rewilding." He thought that Mols had the greatest likelihood of successfully bending the rules due to their stellar institutional reputation - although they themselves seemed relatively uninterested in doing so, at least at the inception of their project. Thus, exceptional sites and 
highly competent individuals with the ability to harness and influence emerging trends in thinking about nature seemed to work synergistically to make rewilding possible in Denmark.

Consolidation: The Formulation of Rewilding Policy in Europe

We now turn from project implementation to the way that high-level policy was developing in parallel. To understand the policy space in which rewilding policy is formulated at the European level, in 2014 one of us (AB) interviewed 17 key informants from ten organizations, including rewilding advocacy NGOs (Rewilding Europe, Wild Europe, and European Wilderness Society), nature conservation NGOs (WWF and Birdlife International), producer organizations and federations (the European Landowner's Organization, the Confederation of European Forest Owners (CEPF), and the Federation of Associations for Hunting and Conservation of the European Union), and unit heads from the Nature and LIFE+ European Commission programmes. The interviews were carried out in English, with nine of the interviews in person in Brussels and the rest by Skype; permission to use names was obtained.

As rewilding became a recognized movement in the UK, the diagnosis of some rewilding proponents was that major environmental NGOs had become dependent for funding on agri-environment and nature stewardship programmes, tying them to the natureas-pastoral-idyll concept and making them "unable" to admit to what these NGOs saw as the superior efficacy of passive management (Fisher, Wildlands Research Institute). This, along with these NGOs' position as privileged informers to the national government on issues concerning biodiversity, lead to a situation of path dependency and institutional inertia (Jordan and Adelle 2013). Several new pan-European rewilding or wilderness preservation organizations emerged to take on both policy-influencing and implementation roles, starting with Wild Europe in 2005, the European Nature Trust in 2007, Rewilding Europe in 2011, 
the Nature Foundation in 2012, and the European Wilderness Society in 2013 (see Table 3). Unlike the site-based rewilding projects previously discussed, these NGOs did not grow out of particular places, but starting from a more conceptual position, sought to set up wilderness networks or spread rewilding to multiple sites throughout Europe.

These organizations had a range of core values and goals. They supported greater protection of large natural habitat areas free from human impacts, which, they claimed, suppress "nature's bounty" (Brunner, Birdlife International). Their views had been shaped by modern understandings of ecological science, including non-equilibrium dynamics, keystone species and trophic cascades, and paleoecological studies and theories about vegetation patterns and megafaunal impacts in ancient Europe. These ideas led to a frustration, generally not shared by the mainstream European environmental NGOs, with the legal requirement to maintain static biodiversity resources and to prevent natural processes such as ecological succession and flooding (Fisher). Rewilding proponents argued that such policies were failures and wastes of money. “...[M]anagement regimes have grown up to protect species and habitats with their betterment in mind, but unfortunately they can keep important ecological and evolutionary processes arrested. This has not been very effective in conservation terms, nor has it been cost effective" (Aykroyd, Wild Europe).

Nevertheless, not all the NGOs had read the ecological literature in the same way. Rewilding Europe supported passive management with herbivores on the basis that grazing and browsing effects on the landscape "didn't start 10,000 years ago when people started to domesticate animals, that it is natural history from millions of years ago" (Helmer, Rewilding Europe). Mark Fisher of the Wildlands Institute and Zoltan Kun of the European Rewilding Society, by contrast, were against grazing and what it represented: “There are people saying you can restore things in the presence of herbivores? This is a basic misunderstanding and ecological illiteracy about what happens to a landscape" (Fisher). Fisher cited 
Oostvardersplassen as an example of this fallacy: "If you take away all the elements of a trophic cascade you end up with the loss of your vegetation and a landscape which is really disastrous for wild nature." Similarly, Toby Aykroyd of Wild Europe felt that "grazing doesn't have a place in wilderness restoration where the emphasis is on integrity of whole ecosystems. There is a difference between natural and naturalistic." These organizations supported reintroducing wolves and other predators to induce top-down trophic control. Although there were theoretical cleavages between the different rewilding groups, they were united in their critique of the ecological basis for existing conservation policy.

Combined with the ecology-based critique was a perception that rewilding could be a solution to problems of agricultural and rural policy, in both the UK and the Netherlands. The dominance of private farming interests in rural policy and the lack of any significant areas of public land for nature led to the "public's complete and utter disenfranchisement from decisions about the countryside" (Fisher). Thus, rewilding organizations believed it was crucial to separate agriculture and nature conservation at a time when agriculture was modernising and intensifying in ways that were "not at all compatible with nature conservation” (Helmer). They saw agricultural land abandonment in Eastern Europe as an opportunity for rewilding.

Rewilding thus framed itself as fundamentally contrary to the assumptions about equilibrium ecosystem dynamics and cultural landscapes at the core of the EU's policy approach. The rewilding NGOs were astute in finding institutional venues to promote this radically different view. In the mid-2000s Wild Europe took the European Parliament as an initial venue for its lobbying efforts, foregrounding the health and societal benefits of wilderness to various parliamentary committees. At several key junctures in past policymaking processes on agriculture and environmental matters (e.g. GMO regulation), the European Parliament has passed popular resolutions lending support to consumer and 
environmental campaigns that have forced the Commission and Council to respond (Faulkner 2007). This appears to be what happened. In November 2008, a Resolution for Wilderness, promoted by Wild Europe, was signed by around 150 NGOs and other organizations. Following this, a special report from the European Parliament called for improved protection and funding of wilderness areas as well as endorsement of the Wild Europe initiative, adopted on 3rd February 2009 by 538 votes to 19 . The Commission responded by producing its own guidelines on "non-intervention management" for wild and wilderness areas within the Natura 2000 network (using Wild Europe definitions) and commissioned a Wilderness Register for Europe (from Wild Europe) which is to include a database and interactive mapping system of wilderness

(http://ec.europa.eu/environment/nature/natura2000/wilderness/index_en.htm). This was followed by the inclusion of rewilding approaches in the application guidelines for Nature and Biodiversity projects in the LIFE+ funding programme in 2014. Thus, by promoting a 'wilderness' policy concept, the rewilding lobby has opened up a policy space in which rewilding appears to be a highly appropriate management approach.

However, the European Commission remained to be convinced of the evidence base for rewilding and was quick to point out the gulf between theory and practice:

If you want to use the tools of nature in a rewilding approach, you have to aim for an equilibrium. If you favour herbivores but don't have the whole trophic chain in good condition, you will have to intervene to limit the damage to human activities and the other habitats which you are trying to protect. We are seeing this now with the wild boar. Do we really understand these dynamics and basic drivers and elements to ensure that a rewilding process is indeed possible in every given context? That is a difficult issue, as we see in countless LIFE projects on species reintroductions: even if we understand the species' biology and behaviour very well in one context, it may be very different in another one. (Salsi)

To date, the European Commission has not produced a Green or White paper on rewilding, signalling that they have not yet validated it as an approach.

Feeling that their gains needed to be shored up, the European Wilderness Society and 
Wild Europe began to "forum shop" for more favourable venues to support wilderness and in 2014 began pushing for a European Wilderness Convention to be hosted by the Council of Europe. This Convention, if adopted, would cover all countries in Europe except Belarusthat is, more countries than are EU members. The hope was that it might act as a catalyst for wilderness policies in the same way that the Bern Convention preceded the 1979 Birds and Habitats Directives. However, to date this process appears to have stalled.

Discussion and conclusions

We find that as rewilding is formulated from individual projects with varying inspirations, goals and strategies, into a policy definition, it risks losing key features of placebased practice, becoming programmatic and success-led, rather than contingent, flexible, and vision-led. We see this, for example, in the second-wave Danish approach to rewilding. While rewilding's expression in Denmark was not a wholesale import of a recognizable model of rewilding, it was a form of nature management inspired by rewilding yet closer in form to naturalistic grazing. Hybrid forms of rewilding fit well into Danish legal regulations. The Danish case maps onto the conservation literature's view on policy, as an expression of cultural values and science, and a codification of practice. This codification of practice arose because it is largely civil servants altering their own practice directly to fit with policy: the feedback loop is very short. Rewilding thus becomes "strangely familiar" (Temenos \& McCann 2013) - a recognisably acontextual landscape of untidy farms or domestic nature areas.

As this process of mobility continues, rewilding assemblages may become a black box (Goulden et al. 2015) where the how and why of the relations are lost, and only the exterior semblances of rewilding are retained. Indeed, the joint mobility of project and policy practices, assumed by the assemblages approach and encapsulated in the notion of the black 
box, may directly lead to translational failures between projects and policies. When the different actors and relations within rewilding assemblages are fixed and move as a unit, they lose site-based adaptability. The first-wave rewilding projects avoided failure by adapting their goals and strategies as they learned about what was locally possible, both ecologically and socially. Failure is rarely evoked in our interviews of rewilding project representatives. Most of the original rewilding projects in the UK and the Netherlands had setbacks and difficulties, but the evolving long-term nature of the projects means that there was no clear timeline or definition of success. One of the features of wildness embraced by these projects is the lack of short-term predictable outcomes, and the flexibility to accept this at a project level is arguably what has allowed these projects to make progress towards long-term visions of landscape transformation. However, the inability to meet predicted short-term ecological targets would be a very legible policy failure. The forms of rewilding action that are not amenable to short-term target-reaching are among the most likely aspects of rewilding to be occluded in a black box formulation. Busenberg (2004), in his analysis of wildfire policy, has referred to this as a kind of problem deriving from exclusive focus on a single facet of an issue (e.g. large herbivores but not adaptive learning). This can lead to policy failure as ignored problems accumulate over time. In other words, a policy focus on the external form or what of rewilding, while losing the why and how of the internal relations that make projects work, would disfavour rewilding success at the policy level.

At issue here, as we signalled in the Introduction, is the elasticity of the relations between what is produced at the policy level (evidence of success) and what is produced at the project level (adaptive avoidance of failure). If rewilding is mobilized as successful best practice, what is visible to policy makers are external signs that can be used as evidence of predefined success. We saw, for example, that in Danish rewilding projects run by civil servants, project managers have relatively little emotional or intellectual investment in 
rewilding as an approach, but they do have political incentives to avoid failures. For this reason, initial problems with rewilding usually led not to adaptive learning but to project termination. Can rewilding, at the same time as it is mobilized as success-making policy, develop roots deep in the soil of particular localities with their socio-ecological historicities and particularities? Can rewilding projects provide a simulacrum of "best practice" while still retaining "forest level" discretion about goals and strategies?

First, we note that this is the kind of elastic move that rewilding has already been practicing since project inceptions. Most of rewilding practices took on forms that could strategically be read differently from different perspectives: a management practice for large grazers could function simultaneously as CAP-subsidized extensive farming, a Natura-2000 compatible conservation measure, a functional ecology proxy for aurochs or woolly mammoths, and a tourist attraction. Practices were produced through the ability of actors to devise forms of action that either satisficed or avoided multiple regulatory, scientific, and social frameworks simultaneously. Second, the anthropological literature, somewhat ironically, would suggest that in fact most project-policy dynamics work with exactly this divide-success is produced at the policy level without reference to what is going on at street level, for better or worse. The notion that science and other research on rewilding (like this paper) should inform policy so that policy can be good, or in other words fit to practice at street level, is, perhaps, slightly pointless and a little naïve (Hoag 2011; Howlett 2012).

Triumphant claims that rewilding was on the European policy agenda in 2014 seem to be progressing more slowly than anticipated. Claims that rewilding is the next obvious step are, of course, strategic. The caution or lack of interest in adopting wilderness and rewilding policies shown by the European Commission and the Council of Europe suggest that the capture of policy by academics and NGO lobbyists also depends on their ability to cast rewilding as enacting success - but how? Optimistically, we would like to suggest that a 
better nature conservation policy that would accommodate rewilding would be one that set targets for site-based innovation and long-term adaptation, rather than particular restoration techniques or ecological conditions. If freedom to take risks and to avoid failure by changing goals is not enshrined in policy, for example through delegating goal-setting powers or decision-making processes to site-level control, the next generation of rewilding projects may become significantly tamer. This is similar to the proposal for results-based agrienvironment schemes (Burton \& Schwartz 2013), except that rather than mandating that land managers do whatever they want as long as they get biodiversity results (which preserves the problems with short-term predicted outcomes), we suggest that land managers do whatever they want as long as they set long-term process goals, use adaptive learning, and take site history and socio-ecological specificities into account in their biodiversity management (this, obviously, would radically change evaluation procedures). Otherwise, rewilding's technical aspects of function-based ecological management could simply become another mechanism for the uniformization of nature areas. This would be a waste.

Acknowledgements: MR-B thanks Pil Pedersen for sharing her contacts with Danish rewilding projects, Elain Gan for driving her to St. Raabjerg, and Jens-Christian Svenning for funding from the VILLUM Investigator project "Biodiversity Dynamics in a Changing World" funded by VILLUM FONDEN, in support of the Danish fieldwork. During the preparation of this paper MR-B was funded by the Danish National Research Foundation Niels Bohr professorship project Aarhus University Research on the Anthropocene (AURA), and a Marie Curie FP7 COFUND Agreenskills Plus fellowship. JG thanks Paul Jepson and the many individuals who shared their rewilding experiences and knowledge with her. Her research was funded by the Oxford BCM Grant Facility and the Dean of Graduates' Research Fund at Oxford's Pembroke College. 
References

Alpert, P., \& Keller, A. (2003). Ecology-Policy Interface. Frontiers in Ecology and the Environment, 1.

Armstrong, J., D, Bello, V., Gilson, J. \& Spini, D. 2010. Civil Society and International Governance : The role of non-state actors in the EU, Africa, Asia and Middle East, London, Routledge

Benson, D., \& Jordan, A. (2011). What have we learned from policy transfer research? Dolowitz and Marsh revisited. Political Studies Review 9, 366-378.

Bunce, R. G. H., Bogers, M. M. B., Evans, D. \& Jongman, R. H. G. 2013. Field identification of habitats directive Annex I habitats as a major European biodiversity indicator. Ecological Indicators, 33, 105-110.

Burton, R. J., \& Schwarz, G. (2013). Result-oriented agri-environmental schemes in Europe and their potential for promoting behavioural change. Land Use Policy, 30(1), 628641.

Busenberg, G. 2004. Wildfire management in the United States: the evolution of a policy failure. Review of policy research, 21(2), 145-156.

Callicott, J. B., Crowder, L. B., \& Mumford, K. (1999). Current normative concepts in conservation. Conservation biology, 13(1), 22-35.

Corlett, R.T., 2016a. Restoration, reintroduction, and rewilding in a changing world. TREE 31(6), 453-462.

Corlett, R.T. 2016b. The role of rewilding in landscape design for conservation. Current Landscape Ecology Representations 1(3), 127-33.

Donald, P. F., Sanderson, F. J., Burfield, I. J., Bierman, S., M, Gregory, R., D \& Waliczky, Z. 2007. International Conservation Policy Delivers Benefits for Birds in Europe. Science, 317, 810-813.

European Commission 2016. Fitness Check of the EU Nature Legislation (Birds and Habitats Directives) http://ec.europa.eu/environment/nature/legislation/fitness_check/docs/nature_fitness_ check.pdf

Faulkner, R. 2007. The political economy of "normative power" Europe: EU environmental leadership in international biotechnology regulation'. Journal of European Public Policy 14, 507-526.

Ferguson, J. 1994. The Anti-Politics Machine: "Development," Depoliticization, and Bureaucratic Power in Lesotho. Minneapolis, MN: University of Minnesota Press.

Galetti, M., Pires, A.S., Brancalion, P.H.S., Fernandez, F.A.S., 2017. Reversing defaunation by trophic rewilding in empty forests. Biotropica 49(1), 5-8.

Galetti, M., Root-Bernstein, M., \& Svenning, J. C. (2017). Challenges and opportunities for rewilding South American landscapes. Perspectives in Ecology and Conservation, 15(4), 245-247.

Gooden, J. 2016. The red tape of rewilding. ECOS, 37(2), 11-18.

Goulden, S., Erell, E., Garb, Y., \& Pearlmutter, D. 2017. Green building standards as sociotechnical actors in municipal environmental policy. Building Research \& Information, 45(4), 414-425.

Gorur, R. 2011. Policy as assemblage. European Education Research Journal. 10(4), 611622.

Greenwood, J. 2011. Interest representation in the European Union, New York, Palgrave Macmillan

Haigh, N. 1992. Manual of Environmental Policy, Harlow, UK, Longman.

Haslett, J. R., Berry, P. M., Bela, G., Jongman, R. H. G., Pataki, G., Samways, M.J. \& Zobel, 
M. 2010. Changing conservation strategies in Europe: A framework integrating ecosystem services and dynamics. Biodiversity and Conservation, 19, 2963-2977.

Heyman, J. McC. 1995. Putting power in the anthropology of bureaucracy: The Immigration and Naturalization Service at the Mexico-United States border. Current anthropology, 36(2), 261-287.

Hoag, Colin. 2011. Assembling Partial Perspectives: Thoughts on the Anthropology of Bureaucracy. PoLAR: Political and Legal Anthropology Review 34(1), 81-94.

Hoag, C. 2014. Dereliction at the South African Department of Home Affairs: Time for the anthropology of bureaucracy. Critique of Anthropology 34(4), 410-428.

Howlett, M. 2013. The lessons of failure: learning and blame avoidance in public policymaking. International Political Science Review 33(5), 539-555.

Jackson, A.L.R. 2013. With the eyes of history; the Natura 2000 network, acute land conflicts and the future of EU biodiverstiy policy. Ph.D, Trinity College Dublin.

Jepson, P. 2016. A rewilding agenda for Europe: creating a network of experimental reserves. Ecography 39, 117-124.

Jepson, P. (2018). Recoverable Earth: a twenty-first century environmental narrative. Ambio, $1-8$.

Jepson, P., \& Canney, S. 2003. Values-led conservation. Global Ecology and Biogeography, 12(4), 271-274.

Jepson, P., \& Schepers, F. 2016. Making space for rewilding: creating an enabling policy environment. Policy brief. DOI: 10.13140/RG.2.1.1783.1287

Jordan, A., \& Adelle, C. (2013). EU Environmental policy at 40: Retrospect and prospect.

Jørgensen, D. 2015. Rethinking rewilding. Geoforum, 65, 482-488.

Kintisch, E. 2015. Born to rewild. Science, 350(6265), 1148-1151.

Lenschow, A. 2013. Studying EU environmental policy. Environmental policy in the EU: Actors, institutions and processes. Third edition ed. ed. Abingdon: Routledge,.

Lorimer, J. \& Driessen, C. 2014. Wild experiments at the Oostvaardersplassen: rethinking environmentalism in the Anthropocene. Transactions of the Institute of British Geographers, 39, 169-181.

Lorimer, J., Sandom, C., Jepson, P., Doughty, C., Barua, M., \& Kirby, K. J. (2015). Rewilding: Science, practice, and politics. Annual Review of Environment and Resources, 40, 39-62.

Mace, G. M. 2014. Whose conservation?. Science, 345(6204), 1558-1560.

Mertens, K. 2013. Recent Developments in EU Environmental Policy and Legislation. 10, 295- 301.

Mosse, D. 2004. Is good policy unimplementable? Reflections on the ethnography of aid policy and practice. Development and Change 35(4), 639-671.

Nogués-Bravo, D., Simberloff, D., Rahbek, C., \& Sanders, N. J. (2016). Rewilding is the new Pandora's box in conservation. Current Biology, 26(3), R87-R91.

Öjehag-Pettersson, A. (2015). Space craft: Globalization and governmentality in regional development (Doctoral dissertation, Karlstads universitet).

Pereira, H.M. \& Navarro, L.M. 2015. Preface. In Rewilding European Landscapes, Pereira, H.M. \& Navarro, L.M., eds. SpringerOpen, Heidelberg. Pp. v-x.

Pettorelli, N., Barlow, J., Stephens, P. A., Durant, S. M., Connor, B., Schulte to Bühne, H., ... \& du Toit, J. T. (2018). Making rewilding fit for policy. Journal of Applied Ecology, 55(3), 1114-1125.

Robert, A., Fontaine, C., Veron, S., Monnet, A. C., Legrand, M., Clavel, J., ... \& Jiguet, F. 2017. Fixism and conservation science. Conservation Biology 31(4), 781-788. 
Root-Bernstein, M., Galetti, M., \& Ladle, R. J. (2017). Rewilding South America: ten key questions. Perspectives in Ecology and Conservation, 15(4), 271-281.

Rocheleau, D.E. 2008. Political ecology in the key of policy: From chains of explaination to webs of relation. Geoforum 39, 716-727.

Rubenstein, D. R., Rubenstein, D. I., Sherman, P. W., \& Gavin, T. A. 2006. Pleistocene Park: Does re-wilding North America represent sound conservation for the 21st century?. Biological Conservation, 132(2), 232-238.

Sandom, C., et al. 2012 Rewilding. Key Topics in Conservation Biology 2, pp. 430-451

Scheuer, S. E. 2005. EU Environmental Policy Handbook. A Critical Analysis of EU Environmental Legislation. Making it accessible to environmentalists and decision makers.

Seddon, P.J., Griffiths, C.J., Soorae, P.S., \& Armstrong, D.P. 2014. Reversing defaunation: Restoring species in a changing world. Science 345(6195), 406-412.

Stone, D. 2017. Transfer of policy failure: Bricolage, experimentalism and translation. Policy and Politics, 45(1), 55-70.

Svenning, J.C., Pedersen, P.B., Donlan, C.J., Ejrnæs, R., Faurby, S., Galetti, M., Hansen, D.M., Sandel, B., Sandom, C.J., Terborgh, J.W., Vera, F.W., 2016. Science for a wilder Anthropocene: Synthesis and future directions for trophic rewilding research. PNAS 113(4), 898-906.

Tallis, H., Lubchenco, J., Adams, V. M., Adams-Hosking, C., Agostini, V. N., \& KovácsHostyánszki, A. 2014. Working together: a call for inclusive conservation. Nature, 515(7525), 27-28.

Telesca, J.E. 2015. Consensus for whom? Gaming the market for Atlantic Bluefin Tuna through the empire of bureaucracy. The Cambridge Journal of Anthropology 33(1), 49-64.

Temenos, C., \& McCann, E. 2013. Geographies of policy mobilities. Geography Compass 7(5), 344-357.

Watson, R. T. 2005. Turning science into policy: challenges and experiences from the science-policy interface. Philosophical Transactions of the Royal Society of London B: Biological Sciences, 360(1454), 471-477.

Webber, S. 2015. Mobile adaptation and sticky experiments: Circulating best practices and lessons learned in climate change adaptation. Geographical Research, 53(1), 26-38.

Wilder BT, Betancourt JL, Epps CW, Crowhurst RS, Mead JI, et al. 2014. Local Extinction and Unintentional Rewilding of Bighorn Sheep (Ovis canadensis) on a Desert Island. PLoS ONE 9(3): e91358. 
Figure 1. The three major policy frames currently used in EU nature conservation policy, and their overlapping concepts.

Figure 2. Sites in the UK and the Netherlands. Top left, rewilding has benefitted water quality in the Ennerdale Valley. Top right, saplings emerge through the grasses at a Trees for Life reforestation site. Bottom, an experimental exclosure at the Oostvaardersplassen shows the impact of grazing. All photos $\mathbb{C}$ JG.

Figure 3. Images from the visited Danish rewilding sites. Top left, livestock shelter from Geding Kasted Mose; top right, cattle and standing deadwood at St. Raabjerg; bottom left, Lille Vildemose, recovering high bog, and "beware of moose" sign; bottom right, horse release at Mols National Park. Photo of cattle at St. Raabjerg (C) Elain Gan, all others (C) MRB. 


\begin{tabular}{|c|c|c|}
\hline Project/Site & Nation & Description \\
\hline $\begin{array}{l}\text { Alladale Wilderness } \\
\text { Reserve }\end{array}$ & Scotland & $\begin{array}{l}8,000 \text {-ha private estate, acquired in } \\
2003 \text { for restoration with native flora } \\
\text { and fauna. Formerly groomed as a } \\
\text { deer stalking estate, restoration } \\
\text { activities on the reserve have } \\
\text { included planting of } 800,000 \text { trees } \\
\text { over } 240 \text { ha and experimental animal } \\
\text { reintroductions (Highland cattle, } \\
\text { moose, wild boar, red squirrel) in } \\
\text { various scales of enclosure. The } \\
\text { long-term vision is a South African } \\
\text { safari model of wilderness tourism. }\end{array}$ \\
\hline $\begin{array}{l}\text { Cairngorms } \\
\text { National Park }\end{array}$ & Scotland & $\begin{array}{l}\text { 4,500-sq km national park in } \\
\text { northeast Scotland. Established in } \\
\text { 2003, the park includes many } \\
\text { properties, three-fourths of which are } \\
\text { privately owned, with the balance } \\
\text { held by NGOs and government. A } \\
\text { number of large adjoining estates in } \\
\text { the western part of the park } \\
\text { implement practices consistent with } \\
\text { rewilding, such as Glenfeshie, a } \\
\text { private estate owned by Wild Land } \\
\text { Ltd, amongst others. }\end{array}$ \\
\hline Dundreggan Estate & Scotland & $\begin{array}{l}4,000 \text {-ha site in the Scottish } \\
\text { Highlands. Formerly groomed for } \\
\text { deer stalking, Dundreggan was } \\
\text { purchased in } 2008 \text { by Trees for Life, } \\
\text { an established conservation volunteer } \\
\text { organization. Projects include aspen } \\
\text { regeneration, wild boar introduction } \\
\text { in enclosure, mountain woodland tree } \\
\text { planting in exclosure, and a tree } \\
\text { nursery. In total } 80,000 \text { trees have } \\
\text { been planted at the Dundreggan } \\
\text { Estate. }\end{array}$ \\
\hline Ennerdale & England & $\begin{array}{l}4,700 \text {-ha valley in England's Lake } \\
\text { District. Most of the property in the } \\
\text { valley is held by three landowners: } \\
\text { the National Trust, an environmental } \\
\text { charity; the English Forestry } \\
\text { Commission, a government agency; } \\
\text { and United Utilities, a private } \\
\text { corporation. These entities, together } \\
\text { with Natural England, a government } \\
\text { agency, make up the entity Wild }\end{array}$ \\
\hline
\end{tabular}




\begin{tabular}{|c|c|c|}
\hline & & $\begin{array}{l}\text { Ennerdale, which manages the } \\
\text { valley. Activities have included } \\
\text { planting } 40,000 \text { trees, creating } 25 \text { ha } \\
\text { of heathland, restoring } 6 \text { ha of bog, } \\
\text { restoring natural stream flow, and } \\
\text { improving habitat for target species. } \\
\text { Wild Ennerdale has also made } \\
\text { changes to agricultural grazing in the } \\
\text { valley, reducing livestock density } \\
\text { and transitioning from sheep to } \\
\text { Galloway cattle. }\end{array}$ \\
\hline Knepp Castle Estate & England & $\begin{array}{l}\text { 1,400-ha site in Sussex, England. } \\
\text { The estate has been privately owned } \\
\text { by the Burrell family for over } 220 \\
\text { years. Previous intensive grazing } \\
\text { activities have given way to } \\
\text { extensive grazing by rare and } \\
\text { heritage breeds, including Longhorn } \\
\text { cattle, Exmoor horses, and Tamworth } \\
\text { pigs. Deer stalking and reduction of } \\
\text { livestock density have allowed forest } \\
\text { to regenerate, and removal of } \\
\text { drainage systems and restoration of } \\
\text { the natural flow of the River Adur } \\
\text { have created habitat for water birds } \\
\text { and aquatic species. }\end{array}$ \\
\hline Blaeneinion & Wales & $\begin{array}{l}\text { 30-ha property purchased by a } \\
\text { private trust in } 2008 \text { with aspirations } \\
\text { to create a conservation, recreation, } \\
\text { and educational resource. At this site, } \\
\text { creation of habitat is practiced } \\
\text { alongside permaculture-based market } \\
\text { gardening activities. To date } 24,000 \\
\text { trees have been planted on } 20 \text { ha, and } \\
\text { European beavers have been } \\
\text { reintroduced in an enclosure. }\end{array}$ \\
\hline Millingerwaard & Netherlands & $\begin{array}{l}\text { Part of the Gelderse Poort network of } \\
\text { habitat projects along the Waal } \\
\text { River. Formerly a hunting estate, the } \\
\text { 375-ha reserve was developed in } \\
\text { connection with a land reallocation } \\
\text { project along the river and a brick } \\
\text { manufacturing facility that extracts } \\
\text { clay from the area. Millingerwaard is } \\
\text { owned by the Dutch Forestry } \\
\text { Commission (Staatsbosbeheer) and } \\
\text { managed in partnership with WWF- }\end{array}$ \\
\hline
\end{tabular}




\begin{tabular}{|l|l|l|}
\hline & $\begin{array}{l}\text { Netherlands and the ARK } \\
\text { Foundation. Grazing animals, } \\
\text { including Galloway cattle and Konik } \\
\text { horses, are owned and managed by } \\
\text { the Foundation for Restoring } \\
\text { European Ecosystems (FREE) in a } \\
\text { naturalistic grazing scheme. Beavers } \\
\text { have been reintroduced, and wild } \\
\text { boar have migrated in from } \\
\text { Germany. }\end{array}$ \\
\hline Oostvaardersplassen & Netherlands \\
& $\begin{array}{l}\text { a 5,600-ha polder reclaimed from } \\
\text { Lake Marker (Markermeer) in 1968, } \\
\text { secured with a system of dykes, } \\
\text { which attracted a variety of birds of } \\
\text { conservation interest. Currently } \\
\text { owned by the Dutch Forestry } \\
\text { Commission (Staatsbosbeheer), it } \\
\text { was named a Ramsar wetland in } \\
\text { 1989, and Heck cattle, Konik horses, } \\
\text { and red deer (Cervus elaphus) were } \\
\text { introduced in the same year. The } \\
\text { Oostvaardersplassen is a flagship } \\
\text { rewilding project, known for its strict } \\
\text { naturalistic grazing scheme. }\end{array}$ \\
\hline
\end{tabular}

Table 1. Description of sites in the UK and the Netherlands.

\begin{tabular}{|l|l|l|}
\hline Project/ Site & Nation & Description \\
\hline $\begin{array}{l}\text { Lille Vildemose, } \\
\text { Aalborg Municipality }\end{array}$ & Denmark & $\begin{array}{l}\text { At 7,500 ha, the largest protected area in } \\
\text { Denmark. Part of the area was bought } \\
\text { from the government by the private O. } \\
\text { Jensen's Fund in 1989. It has 2000 ha } \\
\text { of raised bog, the largest in Europe and } \\
\text { a Natura 2000 area. Originally a peat- } \\
\text { extraction zone viewed as an industrial } \\
\text { wasteland, since 2007 the goal is to } \\
\text { restore the raised bog by raising the } \\
\text { water level and preventing tree } \\
\text { establishment with large browsers. } \\
\text { They reintroduced moose and red deer } \\
\text { starting in 2015. Plan to reintroduce } \\
\text { bison and horses, and hope to attract } \\
\text { wolves and beavers. Only part of the } \\
\text { protected area is designated as a } \\
\text { rewilding area. }\end{array}$ \\
\hline Gedding Kasted Mose, & Denmark & A 62 ha area, protected in order to \\
\hline
\end{tabular}




\begin{tabular}{|c|c|c|}
\hline Aarhus Municipality & & $\begin{array}{l}\text { preserve the municipal groundwater } \\
\text { supply. They plan to introduce } \\
\text { waterbuffalo, and have Konig ponies } \\
\text { since } 2017 \text { and Galloway cattle since } \\
2016 \text {. Uses High Nature Value } \\
\text { agricultural subsidies to pay for the } \\
\text { project. }\end{array}$ \\
\hline $\begin{array}{l}\text { St. Raabjerg, Praesteflod } \\
\text { and Grene Sands site, } \\
\text { Billund Municipality }\end{array}$ & Denmark & $\begin{array}{l}\text { A Natura } 2000 \text { site with a rare stand of } \\
\text { dead trees following an accidental fire. } \\
\text { In order to maintain the deadwood } \\
\text { without allowing succession to forest, } \\
\text { use year-round grazing by Galloway } \\
\text { cattle. To remove nutrients and } \\
\text { promote protected heath formation on } \\
\text { inland dunes, they graze former } \\
\text { hayfields for } 3 \text { months a year with } \\
\text { cattle. They pay for the project with } \\
\text { High Nature Value agricultural } \\
\text { subsidies. }\end{array}$ \\
\hline Mols National Park & Denmark & $\begin{array}{l}\text { An } 18,000 \text { ha area owned by the Natural } \\
\text { History Museum in Aarhus, it is classed } \\
\text { as farmland. Since } 2016 \text { it as } 12 \\
\text { Exmoor ponies and } 13 \text { Galloway cattle } \\
\text { within a } 130 \text { ha rewilding area. } \\
\text { Intended as a showcase for rewilding on } \\
\text { private lands, with culling of the } \\
\text { animals managed according to scientific } \\
\text { principles. }\end{array}$ \\
\hline $\begin{array}{l}\text { Klosterheden beaver } \\
\text { reintroduction, } \\
\text { Vestjylland Municipality }\end{array}$ & Denmark & $\begin{array}{l}\text { The site was chosen as the most suitable } \\
\text { for a national beaver reintroduction } \\
\text { program. } 18 \text { beavers were released in } \\
1999 \text {. There are now approximately } \\
180 \text { beavers, which have dispersed up to } \\
200 \mathrm{~km} \text {. It is hoped that they can } \\
\text { disperse naturally throughout Denmark. } \\
\text { When they cause flooding on } \\
\text { agricultural land, the dam must be } \\
\text { modified or they may be removed and } \\
\text { released elsewhere. }\end{array}$ \\
\hline Kleland Deer Park & Denmark & $\begin{array}{l}\text { A privately owned deer park not } \\
\text { managed for hunting but rather for } \\
\text { biodiversity, it has reintroduced red deer } \\
\text { and wild boar. }\end{array}$ \\
\hline $\begin{array}{l}\text { Bornholm Island, } \\
\text { Bornholm Municipality }\end{array}$ & Denmark & $\begin{array}{l}\text { Reintroduction in } 2012 \text { of a } \\
\text { reproductive herd of } 7 \text { European bison } \\
\text { on the island into a } 200 \text { ha area, for } \\
\text { evaluation for release onto the whole } \\
\text { island }(9,000 \text { ha). }\end{array}$ \\
\hline $\begin{array}{l}\text { Wild Horses of } \\
\text { Langeland, Fyn }\end{array}$ & Denmark & $\begin{array}{l}\text { "The wild horses of Langeland" are } \\
\text { around } 60 \text { Exmoor ponies. Also have }\end{array}$ \\
\hline
\end{tabular}




\begin{tabular}{|l|l|l|}
\hline & $\begin{array}{l}10 \text { cattle at the } 100 \text { ha site. The goal } \\
\text { was to create both a tourist attraction } \\
\text { and nature conservation. }\end{array}$ \\
\hline
\end{tabular}

Table 2. The main Danish projects discussed in the study. 